\title{
How To Speak Up and Be Heard: Self Advocacy
}

Community of Practice, Northeast Massachusetts 2014

SELF ADVOCACY IS THE ABILITY TO SPEAK UP FOR YOURSELF AND FOR THE THINGS THAT ARE IMPORTANT TO YOU. AS YOU BECOME OLDER AND TAKE ON MORE RESPONSIBILITIES IN YOUR LIFE, SELF ADVOCACY HELPS YOU:

- Get what you need

- Learn how to say no

- Make your own choices

- Express your feelings respectfully

Places to Use Self Advocacy

- Adjusting your schedule

- Participating in meetings

- Asking for

AT WORK OR SCHOOL

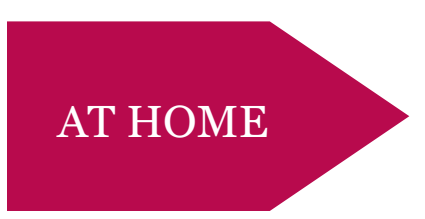

- Managing finances (bills/ roommates)

- Requesting personal space/time

- Renting an apartment

- Sharing food costs

- In a relationship

- Arranging transportation

IN THE COMMUNITY

- Presenting in court

- Making a complaint

- Paying a check

- Making an appointment

- Reviewing a treatment or

AT THE DOCTORS OFFICE recovery plan

- Requesting a second opinion

- Asking for clarification

\section{Putting it Into Words}

- Aт School: E-mail to professor: "I am asking for a week extension for this assignment. I haven't been feeling well and I fell behind."

- Ат Work: "I can't work on Sunday, I have a family commitment. Can I work a different shift instead?"

- With Roommates: "I have class at 8 A.M. Can you stop playing your music by 10 P.M.?”

- Argument with a Significant Other: "I need to remove myself from this conversation, could we talk about this later when we are both feeling less angry?”

- At the Bank: "I don't understand this statement, can you explain the fees to me?"

- Splitting a Check: "I'd love to go out to dinner. Can we split the check?"

- At the Doctor: "Before we make a final decision, I would like to get a second opinion."

- Medical Appointment: "The side effects of this medication are bothering me. Can we discuss other options or choices?" 


\section{Ways to be Heard}

\begin{tabular}{|l}
\hline 1. \\
2. Lisk questions. \\
3. Think before you speak. People listen when you choose your words carefully. \\
4. Write down your thoughts and/or rehearse what you will say with a friend or in a mirror. \\
5. $\quad$ Speak to others in the way you want to be spoken to. \\
6. Know to whom you are talking. For example, friend, grandparent, or boss and use language \\
7. $\quad$ Know when to stop talking and how to exit a conversation politely. \\
8. Be willing to compromise and be flexible. \\
9. Using words like "please" and "thank you" go a long way. \\
10. Do your research. Find out if what you're asking for is reasonable.
\end{tabular}

\section{Questions to Ask Yourself}

If you are getting ready to advocate for something you need, think about the questions below. You can review your answers with someone you trust. Role-playing the scenario can also help you to figure out exactly what you want to say and how.

1. What am I advocating for? What do I want?

2. Why is it important?

3. How should I make my request?

4. Who do I need to talk to?

5. Who else will this affect?

6. Is there a compromise or another option?

7. What should I do if my request is denied?

\section{For additional information on self advocacy visit these websites:}

http://www.ncwd-youth.info/tip-sheet/becoming-a-self-advocate, http://www.selfadvocacyonline.org/learning/

SAMHSA Guide on self advocacy: http://store.samhsa.gov/shin/content/SMA-3719/SMA-3719.pdf

\begin{tabular}{|c|c|c|}
\hline UMASS. & $\begin{array}{l}\text { Visit us at: http://www.umassmed.edu/TransitionsRTC } \\
\text { Recommended citation: Northeast Massachusetts Community of Practice. (2014). How to Speak Up and Be Heard: } \\
\text { Self Advocacy. Worcester, MA: University of Massachusetts Medical School, Department of Psychiatry, Systems and } \\
\text { Psychosocial Advances Research Center. }\end{array}$ & \\
\hline SPARC & This publication can be made available in alternative formats upon request through TransitionsRTC@umassmed.edu & $\triangle \mathbf{5 A M H S A}$ \\
\hline \multicolumn{3}{|c|}{$\begin{array}{l}\text { The contents of this tip sheet were developed with funding from the US Department of Education, National Institute on Disability and Rehabilitation Research, and the Center for Mental } \\
\text { Health Services, Substance Abuse and Mental Health Services Administration (NIDRR grant H133B090018). Additional funding provided by UMass Medical Schools Commonwealth } \\
\text { Medicine division. The content of this tip sheet does not necessarily reflect the views of the funding agencies and you should not assume endorsement by the Federal Government. }\end{array}$} \\
\hline & $\begin{array}{c}\text { The Transitions RTC is part of the Systems \& Psychosocial Advances Research Center (SPARC) } \\
\text { A Massachusetts Department of Mental Health Research Center of Excellence }\end{array}$ & \\
\hline
\end{tabular}

